\title{
The Effect Of Motivation And Compensation On Employee Performance With Work Satisfaction As Intervening (Case Study In The Technical Department of Pt Semen Padang)
}

\author{
Rusman Hidayat \\ Master of Management, STIE "KBP ", \\ JL Khatib Sulaiman No. 61 Lolong Belanti, \\ Padang Utara 25136, West Sumatra, Indonesia \\ Heryanto \\ Lecturer in Management Master Program, STIE "KBP", \\ JL Khatib Sulaiman No. 61 Lolong Belanti, \\ Padang Utara 25136, West Sumatra, Indonesia
}

\begin{abstract}
This study aims to determine the effect of motivation, compensation and job satisfaction on employee performance. The population in this study amounted to 285 employees and a sample of 167 respondents. This research was conducted in the Engineering Department, PT. Semen Padang by using primary data obtained through questionnaires. The data analysis technique used is Path Analysis technique and is operated through SPSS 16.0. The results showed that motivation had a significant effect on job satisfaction, compensation had a significant effect on job satisfaction, job satisfaction had a significant effect on employee performance, motivation and compensation directly had a significant effect on employee performance, motivation through job satisfaction had a significant effect on employee performance, compensation through satisfaction work on performance has no significant effect.
\end{abstract}

Keywords: motivation, compensation, job satisfaction, employee performance

\section{INTRODUCTION}

The era of globalization has had an impact in the business world, globalization has caused intense competition among companies to get the targeted market share. With globalization, the business world is inevitably encouraged to achieve an effective and efficient company. Effectiveness and efficiency in a company is needed so that the company can have more competitiveness and excellence than competitors, so that the company can survive in a world of intense competition.

The company is an organization consisting of a group of people who work to achieve a goal. The most basic interest is to get the maximum profit or profit and the welfare of the company's shareholders (Prastusi, 2014). To achieve a company that is effective and efficient is very much determined by the Human Resources (HR) owned by the company, where Human Resources have an important role as a potential driver of all company activities. The importance of human resources in an organization or company requires every organization to have productive employees to run the organization (Kalangi, 2015).

Human resources are the main assets in every activity of the company. Employees as human resources in the company is a great potential to carry out company activities (Afriansyah, 2014). This really needs attention, because these factors will affect work performance, dedication, and loyalty and love of work and company. So the company must be able to create 
conditions that can encourage or enable employees to develop and improve their abilities and skills that are owned optimally.

Therefore, every company will always strive to improve the performance of its employees, in order to achieve company goals. Efforts that can be taken by the company include motivating employees through applying compensation in accordance with their abilities so that job satisfaction can be achieved, employees who feel satisfied will be more loyal and their performance will increase in the company.

Employee performance is the work of both quality and quantity produced by employees or real behavior that is displayed in accordance with the responsibilities given to him (Murty and Hudiwinarsih, 2012). Performance is also the result of work produced or donated by an employee relating to duties and responsibilities to the company (Mangkunegara, 2013). With good employee performance, the company is expected to be able to compete with other companies so that it can be recognized that the company has a quality performance. Employee performance can be improved through increasing compensation and work motivation, because the compensation given by the company to employees, enthusiasm, willingness, and accuracy of employees at work will be more maximal, focused, and disciplined (Damayanti, 2013).

Job satisfaction is an important condition that must be owned by every employee who works, where humans are able to interact with their work environment and they will work passionately and earnestly so that the contribution to the achievement of company goals will increase (Kunartinah, 2012). Employee satisfaction is a phenomenon that needs to be observed by the company leadership. Employee job satisfaction is closely related to employee performance. Someone who is satisfied will have high motivation and work participation, which in the end will continue to improve their performance (Hasibuan, 2008).

Employee motivation is very important to be maintained because it is closely related to passion and enthusiasm for work, if work motivation is high then the employee's performance will be high. Company leaders should strive so that employees can continue to have high and increasing motivation, to achieve company goals. Motivation and expectations of employees to get appropriate compensation make employees work optimally in order to achieve high performance for employees. Murty and Hudiwinarsih (2012) state that a motivated employee will be energetic and enthusiastic, and conversely an employee with low motivation will often display discomfort and displeasure with his work which results in their performance getting worse and company goals will not be achieved.

Compensation for employees is one way to improve employee performance. Where employee performance will increase and can bring up the potential they have if the compensation they receive can meet their needs and improve their welfare. Giving compensation is a strategic function of human resources which has significant effects on other human resource functions (Murty and Hudiwinarsih, 2012). Compensation attracts the attention of employees and provides information or reminds of the importance of something being compensated compared to others, compensation also increases employee motivation towards performance measures, thus helping employees allocate time and effort to employees.

PT. Semen Padang is the oldest cement producer in Indonesia which was established in 1910, and in 2012 PT. Semen Padang joins under PT. Semen Indonesia (Persero) Tbk with PT. Semen Gresik PT. Semen Tonasa and Thang Long Cement Vietnam. There are many competitors with similar companies that have also been involved in the cement industry since 2014 such as: Indocement, Semen Baturaja, Semen Merah Putih, Holcim, Anhui Conch Cement (China) in 
South Kalimantan and many more are still in the process of establishing factories established by foreign parties. This has an impact on the national market share for PT. Semen Padang, this proved to be decreasing, which is found in the annual report of PT. Semen Padang in 2017. On the annual report of PT. Semen Padang in 2017, there is also information about the current year's net income report which shows a decline. The following is a graph of current year's earnings of PT. Semen Padang in 2017. PT. Semen Padang made an effort to make efficiency in everything where it was called Cost Transformation, where one of them was overtime control, optimization in maintenance and repair, and other things that could have a large impact on savings so as to create the expected efficiency target.

From the information obtained, researchers conducted observations in the field and it turned out to have an impact on employee performance. With the condition of a decrease in profits, automatically indirectly affected all things related to employee performance, especially on compensation to be received by employees. Motivation of employees in the company PT. Semen Padang has decreased, because the effect of efficiency has made the work space of employees limited, especially in the factory area, not maximally repair or maintenance of equipment when troubleshooting, often the completion of completion time, when overtime is required at the end of the month, often not responded quickly, due to restrictions on overtime payments, as well as compensation compensation received by employees, resulting in job dissatisfaction by employees.

With these conditions, PT. Semen Padang must immediately improve itself and mobilize all existing potential so that it is not eroded by other cement industry companies. To make this happen, PT. Semen Padang must strive to improve its human resources.

\section{Motivation}

\section{LITERATURE REVIEW}

The high and low performance of an employee is of course determined by the factors that influence it both directly and indirectly. Motivation is a process that moves or encourages someone to do something to achieve to achieve the expected goal (Wake, 2012: 312). Mangkunegara (2013) states that the factors that influence performance achievement are motivational factors.

Motivation is defined as a condition that encourages other people to be able to carry out tasks according to their functions in the organization. Motivation can also be defined as an action to influence other people to behave on a regular basis (Wake up. 2012: 313).

According to Mangkunegara (2013: 93), motivation is an impulse to the needs of employees who need to be fulfilled so that employees can adjust to their environment, while motivation is a condition that drives employees to be able to achieve the goals of their motives. According to Wibowo (2014: 324) motivating techniques must be able to ensure that the environment in which employees work meets a number of important human needs.

Based on the opinions of the experts above, it can be concluded that motivation is an impulse aimed at oneself to arouse enthusiasm and determine behavior in order to achieve the desired goals. To achieve company goals, motivation from leaders plays an important role in employee behavior. 


\section{Compensation}

According to Kadarisman (2016: 48) states that a compensation will clearly be able to increase or decrease work performance, job satisfaction, and work motivation.

According to Samsudin quoted by Kadarisman (2016: 49) compensation contains a broader meaning than wages or salaries. Wages or salaries emphasize remuneration that is financial in nature, while compensation covers financial and non-financial rewards.

According to Syuhadhak quoted by Kadarisman (2016: 30), when viewed from the employee side, compensation is an exchange of services that it provides or in return for work that has been done, so compensation reflects the price of the ability and expertise of employees or appreciation for education and training that has been obtained by employees.

According to Hasibuan quoted by Kadarisman (2016: 19) compensation is all income in the form of direct or indirect goods money received by employees in return for services provided to the organization. Compensation in the form of money, meaning compensation is paid with a number of cards to the employee concerned. Compensation in the form of goods, meaning compensation is paid for with goods. For example, compensation is paid $10 \%$ of the production produced. In West Java, rice harvesters pay $10 \%$ of the rice they harvest.

Compensation is all income received by employees in the form of money, goods directly or indirectly which is a form of costs that must be incurred by the company in the hope of obtaining benefits in the form of work performance from employees (Hasibuan, 2012: 118; Sofyandi, 2008: 159).

\section{Job Satisfaction}

Rivai (2010) defines job satisfaction as an evaluation that describes a person with a feeling of being happy or unhappy, satisfied or not satisfied at work. Robbins (2006) defines job satisfaction as a positive feeling about one's work which is the result of an evaluation of its characteristics. According to George and Jones (2002) job satisfaction is the feeling that employees have about current workplace conditions.

\section{Performance}

Performance is the result of work in quality and quantity achieved by an employee in carrying out his duties in accordance with the responsibilities given to him (Mangkunegara, 2013). Another definition of performance (performance) is the result of work achieved by a person based on job requirements (job requirements).

A job has certain requirements to be able to be carried out in achieving a goal which is also called a work standard (Bangun 2012: 231). Performance improvement is something that all companies want, but it is not easy for companies to improve the performance of their employees. Therefore, a performance management system is needed in order to improve employee performance. The system can provide an overview to the company about the assessment of employee performance, goals and benefits of performance appraisal, measure employee performance and achieve or not the company's goals.

Bangun (2012: 230) defines a performance management system as a process for identifying, measuring, and evaluating employee performance in a company. While performance assessment is a process carried out by the organization to evaluate or assess the success of employees in carrying out their duties. Performance appraisal can be done by comparing work 
results obtained up to or exceeding work standards. If it exceeds then it can be said that the performance of an employee belongs to the good category.

Conversely if it does not reach the standard of work, it is included in the performance that is not good. To facilitate performance appraisal, work standards must be clearly measured and understood. A job can be measured through the amount, quality, timeliness of doing it, attendance, the ability to cooperate that is demanded by a particular job.

\section{Research Conceptual Framework}

From the above theory, the researcher uses the research conceptual framework as follows:

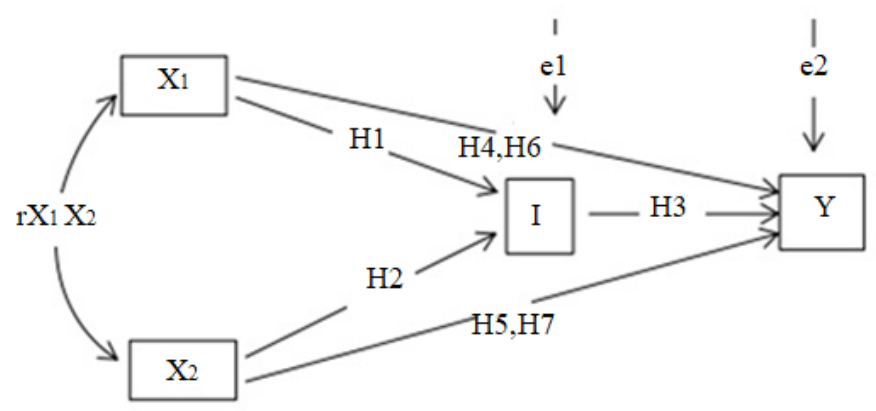

Information :

-X1 = Motivation Variable

-X2 = Compensation Variable

- I = Variable Job Satisfaction

- $\mathrm{Y}=$ Performance Variable

- rX1X2 = Motivation and Compensation Correlation Coefficient

- e1 = Other factors that affect job satisfaction

- e2 = Other factors that affect performance

\section{Hypothesis}

Based on the background, study of the theory and conceptual framework that has been stated above, the hypothesis in this study are:

1. $\mathrm{H} 1$ = Motivation influences job satisfaction.

2. $\mathrm{H} 2=$ Compensation has an effect on job satisfaction.

3. H3 = Job satisfaction has an influence on employee performance.

4. $\mathrm{H} 4=$ Motivation influences performance.

5. $\mathrm{H} 5=$ Compensation has an effect on performance.

6. $\mathrm{H} 6=\mathrm{Job}$ satisfaction acts as an intervening variable between employee motivation and performance.

7. $\mathrm{H7}=$ Job satisfaction acts as an intervening variable between compensation and employee performance.

\section{Types of Research}

\section{RESEARCH METHODS}

This study uses quantitative methods with path analysis (path analysis), where the research variables are motivation, compensation, job satisfaction and employee performance.

\section{Population and Sample}

Population used in this researched is employees in the Engineering Department, PT. Semen Padang g with the population being 285 and the study sample was 167 respondents after using the Slovin formula. 


\section{Data Analysis Technique}

The data analysis technique used is validity test, reliability test, respondent achievement level test, normality test, linearity test, multicollinearity test, heterocedasticity test and path analysis.

\section{RESULTS AND DISCUSSION}

Path analysis in this study has 2 paths, namely

1. Sub Structural 1 (Motivation (X1) and Compensation (X2) to Satisfaction (I)

2. Sub Structural 2 (Motivation (X1) Compensation (X2) Satisfaction (I) to Performance (Y).

\section{Sub Structural Path Coefficient 1}

\begin{tabular}{|ll|r|r|r|}
\hline \multicolumn{1}{|c|}{ Correlations } \\
\hline Motivasi & Motivasi & Kompensasi & $\begin{array}{c}\text { Kepuasan } \\
\text { Kerja }\end{array}$ \\
& Pearson Correlation & 1 & $.671^{\prime \prime}$ & $.792^{\prime \prime}$ \\
& Sig. (2-tailed) & & .000 & .000 \\
& $N$ & 167 & 167 & 167 \\
\hline Kompensasi & Pearson Correlation & $.671^{\prime \prime}$ & 1 & $.724^{\prime \prime}$ \\
& Sig. (2-tailed) & .000 & & .000 \\
& $N$ & 167 & 167 & 167 \\
\hline Kepuasan Kerja & Pearson Correlation & $.792^{\prime \prime}$ & $.724^{\prime \prime}$ & 1 \\
& Sig. (2-tailed) & .000 & .000 & 167 \\
& $N$ & 167 & 167 & \\
& $N$ & &
\end{tabular}

\#. Correlation is significant at the 0.01 level (2-tailed).

\section{Source: Primary data processed with SPSS 16.0, 2018}

The following is the result of $\mathrm{R}$ Square of job satisfaction (I) results of data processing using SPSS 16.0:

Model Summary

\begin{tabular}{|l|l|r|r|r|}
\hline $\begin{array}{l}\text { Mode } \\
\perp\end{array}$ & $\mathrm{R}$ & R Square & $\begin{array}{c}\text { Adjusted R } \\
\text { Square }\end{array}$ & $\begin{array}{c}\text { Std. Error of } \\
\text { the Estimate }\end{array}$ \\
\hline 1 & $.834^{\mathrm{a}}$ & .695 & .692 & 3.55892 \\
\hline
\end{tabular}

a. Predictors: (Constant), Kompensasi, Motivasi

b. Dependent Variable: Kepuasan Kerja

Source: Primary data processed with SPSS 16.0, 2018

The following is the result of the regression effect of motivation (X1) and compensation (X2) on job satisfaction (I) using SPSS 16.0:

\section{Coefficients $^{*}$}

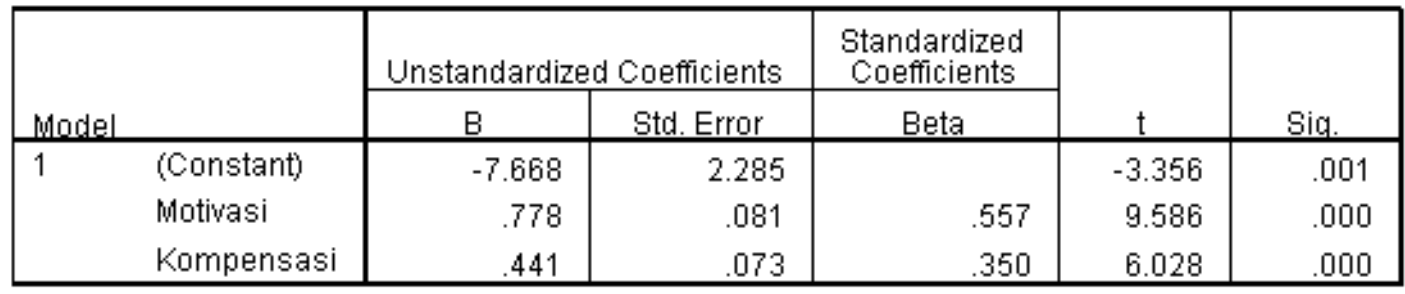

a. Dependent Variable: Kepuasan Kerja

\section{Source: Primary data processed with SPSS 16.0, 2018}


Based on tables the following results are obtained:

1. The value of the correlation between motivation and compensation rX1X2 is 0.671 and the significance value is $0,000<0.05$, meaning that it has a significant effect.

2. Path coefficient

- $\rho \mathrm{IX} 1=$ Motivational path coefficient on job satisfaction $=0.557$

- $\rho \mathrm{IX} 2=$ Compensation path coefficient for job satisfaction $=0.350$

3. Significance value

- From the motivation variable $(\mathrm{X} 1)=0,000<0.05$. This means that motivation has a significant effect on job satisfaction (I).

- From the compensation variable $(X 2)=0,000<0.05$. This means that compensation has a significant effect on job satisfaction (I).

4. For the value of R2 (R Square) contained in table 4.17 is 0.695 or rounded to $70 \%$ is a contribution from the variable motivation and compensation for job satisfaction. While the remaining $30 \%$ is influenced by other factors outside the model. And from the value of R2 (R Square), obtained e1 by means

$$
\mathrm{e} 1=\sqrt{ }(1-\mathrm{R} 2)=\sqrt{ }(1-0,695)=0.552 \text {. }
$$

5 . Based on the above results, the equation in sub-structure 1 is obtained

$$
\mathrm{I}=0.557 \mathrm{X} 1+0.350 \mathrm{X} 2+0.552
$$

This model is significant because $\mathrm{p}$ value $=0.001$ is smaller than $\alpha 0.05$.

From the results of the calculation and processing of sub-structural data 1 , the values of the path diagram are obtained as follows:

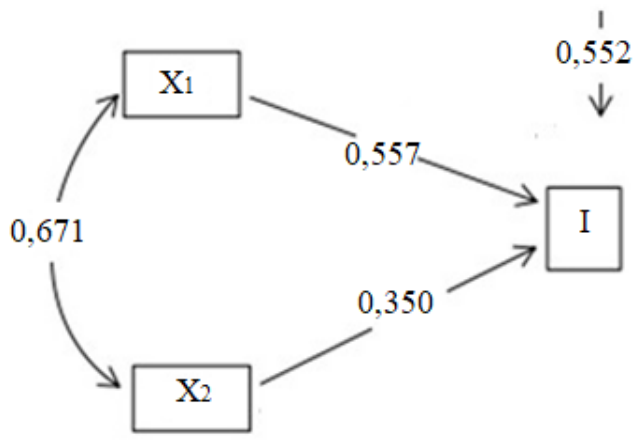

\section{Sub Structural Path Coefficient 2}

The following are the results of the calculation of sub-structural correlation coefficients 2 results of data processing using SPSS 16.0: 


\section{Correlations}

\begin{tabular}{|ll|r|r|r|r|}
\hline & & Motivasi & Kompensasi & $\begin{array}{c}\text { Kepuasan } \\
\text { Kerja }\end{array}$ & Kinerja \\
\hline Motivasi & Pearson Correlation & 1 & $.671^{\prime \prime}$ & $.792^{\prime \prime}$ & $.657^{\prime \prime}$ \\
& Sig. (2-tailed) & & .000 & .000 & .000 \\
& $\mathrm{~N}$ & 167 & 167 & 167 & 167 \\
\hline Kompensasi & Pearson Correlation & $.671^{\prime \prime}$ & 1 & $.724^{\prime \prime}$ & $.621^{\prime \prime}$ \\
& Sig. (2-tailed) & .000 & & .000 & .000 \\
& $\mathrm{~N}$ & 167 & 167 & 167 & 167 \\
\hline Kepuasan Kerja & Pearson Correlation & $.792^{\prime \prime}$ & $.724^{\prime \prime}$ & 1 & $.723^{\prime \prime}$ \\
& Sig. (2-tailed) & .000 & .000 & & .000 \\
& $\mathrm{~N}$ & 167 & 167 & 167 & 167 \\
\hline Kinerja & Pearson Correlation & $.657^{\prime \prime}$ & $.621^{\prime \prime}$ & $.723^{\prime \prime}$ & 1 \\
& Sig. (2-tailed) & .000 & .000 & .000 & \\
& $\mathrm{~N}$ & 167 & 167 & 167 & 167 \\
\hline
\end{tabular}

*. Correlation is significant at the 0.01 level (2-tailed).

Source: Primary data processed with SPSS 16.0, 2018

The following is the result of R Square performance (Y) results of data processing using SPSS 16.0:

Model Summary

\begin{tabular}{|l|l|r|r|r|}
\hline $\begin{array}{l}\text { Mode } \\
1\end{array}$ & $\mathrm{R}$ & $\mathrm{R}$ Square & $\begin{array}{c}\text { Adjusted R } \\
\text { Square }\end{array}$ & $\begin{array}{c}\text { Std. Error of } \\
\text { the Estimate }\end{array}$ \\
\hline 1 & $.745^{\mathrm{a}}$ & .554 & .546 & 2.79131 \\
\hline
\end{tabular}
a. Predictors: (Constant), Kepuasan Kerja, Kompensasi, Motivasi

b. Dependent Variable: Kinerja

Source: Primary data processed with SPSS 16.0, 2018

The following is the result of the regression effect of motivation (X1), compensation (X2) and job satisfaction (I) on performance (Y) using SPSS 16.0:

\begin{tabular}{|c|c|c|c|c|c|c|}
\hline \multicolumn{7}{|c|}{ Coefficients $^{*}$} \\
\hline \multirow{2}{*}{\multicolumn{2}{|c|}{ Madel }} & \multicolumn{2}{|c|}{ Unstandardized Coefficients } & \multirow{2}{*}{$\begin{array}{c}\begin{array}{c}\text { Standardized } \\
\text { Coefficients }\end{array} \\
\text { Beta } \\
\end{array}$} & \multirow[b]{2}{*}{$t$} & \multirow[b]{2}{*}{ Siq. } \\
\hline & & B & Std. Error & & & \\
\hline \multirow[t]{4}{*}{1} & (Constant) & 19.223 & 1.853 & & 10.376 & .000 \\
\hline & Motivasi & .164 & .080 & .182 & 2.063 & .041 \\
\hline & Kompensasi & .136 & .063 & .167 & 2.138 & .034 \\
\hline & Kepuasan Kerja & .296 & .061 & .458 & 4.839 & .000 \\
\hline
\end{tabular}

a. Dependent Variable: Kinerja

\section{Source: Primary data processed with SPSS 16.0, 2018}

Based on tables, the following results are obtained:

1. The value of the correlation between motivation and compensation rX1X2 is 0.671 and the significance value is $0,000<0.05$, meaning that it has a significant effect.

2. Path coefficient

- $\rho Y X 1=$ Motivation Path Coefficient to Performance $=0.182$

- $\rho Y X 2$ = Compensation Path Coefficient to Performance $=0.167$

- $\rho$ YI = Motivation Path Coefficient to Performance $=0.458$

3. Significance value

- From the motivation variable $(\mathrm{X} 1)=0.041<0.05$. This means that motivation has a significant effect on performance $(\mathrm{Y})$. 
- From the compensation variable $(\mathrm{X} 2)=0.034<0.05$. This means that compensation has a significant effect on performance $(\mathrm{Y})$.

- From the variable job satisfaction $(\mathrm{I})=0,000<0,05$. This means that job satisfaction has a significant effect on performance (Y).

4. As for the value of R2 (R Square) contained in table 4.20 is 0.554 or rounded to $55 \%$ is a contribution from the variable motivation, compensation, job satisfaction on performance. While the remaining $45 \%$ is influenced by other factors outside the model. And from the value of R2 (R Square), it is obtained by e2

$$
\mathrm{e} 2=\sqrt{ }(1-\mathrm{R} 2)=\sqrt{ }(1-0,554)=0.667 \text {. }
$$

5 . Based on the above results, the equation in sub-structure 2 is obtained

$$
\mathrm{Y}=0.182 \mathrm{X} 1+0.167 \mathrm{X} 2+0.458 \mathrm{I}+0.667
$$

This model is significant because p value $=0,000$ is smaller than $\alpha 0.05$

From the results of calculation and processing of sub-structural data 2, the values of the path diagram are obtained as follows:

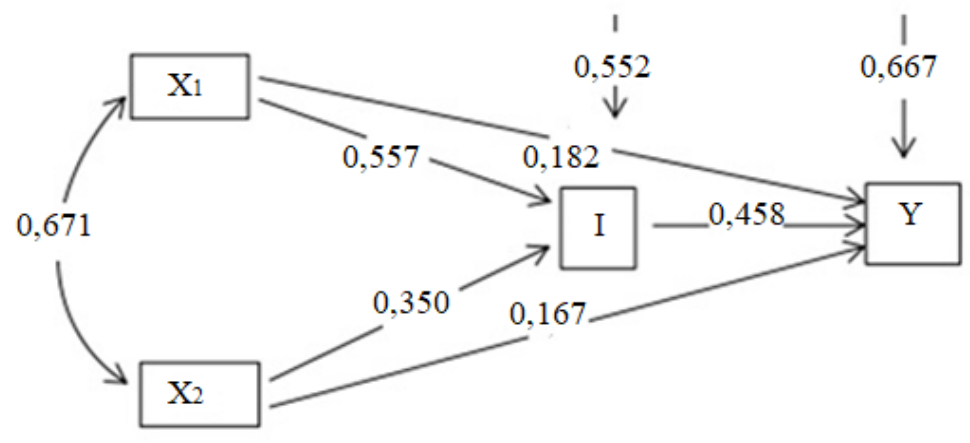

\section{Hypothesis Test Results}

From the two path analysis models, the authors obtained the analysis of the hypothesis results for this study, namely:

1. Analysis of the effect of motivation (X1) on job satisfaction (I);

From the motivation variable $(\mathrm{X} 1)=0,000<0,05$. This means that motivation has a significant effect on job satisfaction (I).

2. Analysis of the effect of compensation (X2) on job satisfaction (I).

From the compensation variable $(\mathrm{X} 2)=0,000<0.05$. This means that compensation has a significant effect on job satisfaction (I).

3. Analysis of the effect of variable job satisfaction (I) on performance (Y).

From the variable job satisfaction (I) $=0,000<0,05$. This means that job satisfaction has a significant effect on performance $(\mathrm{Y})$.

4. Analysis of the effect of motivation variable (X1) on performance (Y).

From the motivation variable $(\mathrm{X} 1)=0.041<0.05$. This means that motivation has a significant effect on performance $(\mathrm{Y})$.

5. Analysis of the effect of compensation variable (X2) on performance (Y).

From the compensation variable $(\mathrm{X} 2)=0.034<0.05$. This means that compensation has a significant effect on performance (Y).

6. Analysis of the effect of motivation variables (X1) through job satisfaction (I) on performance $(Y)$. From the analysis the above variables are obtained: 
- Direct Effect (Direct Effect) given motivation variable (X1) to performance (I) of 0.182 .

- Indirect Effect given by X1 through I to Y variable is the multiplication of beta X1 to I with beta I value to $\mathrm{Y}$ which is $=0.557 \times 0.458=0.255$.

- Total Effect given by motivation $(\mathrm{X} 1)$ on performance $(\mathrm{Y})$ is $=0.182+0.255=$ 0.437.

Based on the results of this calculation, it is known that the direct effect value is 0.182 and the indirect effect value is 0.255 , which means that the value of indirect influence is greater than the value of direct influence. These results indicate that indirectly the motivation variable (X1) through job satisfaction (I) has a significant influence on the performance variable (Y).

7. Analysis of the effect of compensation variables (X2) through job satisfaction (I) on performance $(\mathrm{Y})$. From the analysis the above variables are obtained:

- Direct Effect compensation (X2) to performance (I) of 0.167

- Indirect Effect $\mathrm{X} 2$ through $\mathrm{I}$ to $\mathrm{Y}=0.350 \times 0.458=0.160$

- Total Effect compensation $(\mathrm{X} 2)$ to performance $(\mathrm{Y})=0.164+0.160=0.324$

Based on the results of this calculation, it is known that the direct effect value is 0.167 and the indirect effect value is 0.160 , which means that the value of the indirect effect is 0.007 smaller than the direct influence value. These results indicate that indirectly the compensation variable (X2) through job satisfaction (I) does not significantly influence the performance variable (Y).

\section{Conclusions}

\section{CLOSING}

Based on the results of testing and discussion of the hypotheses described in the previous chapter, some conclusions can be drawn as follows:

1. Motivation has a significant effect on employee job satisfaction of the Department of Engineering PT. Semen Padang. This means that with increasing employee motivation there will also be increased employee job satisfaction at the Department of Engineering PT. Semen Padang.

2. Compensation has a significant effect on employee job satisfaction of the Department of Engineering PT. Semen Padang. This means that with the increase in employee compensation it will also increase employee job satisfaction at the Department of Engineering PT. Semen Padang.

3. Job satisfaction has a significant effect on the performance of employees of the Department of Engineering PT. Semen Padang. This means that with increasing job satisfaction it will also increase the performance of employees of the Engineering Department of PT. Semen Padang.

4. Motivation has a significant effect on the performance of employees of the Department of Engineering PT. Semen Padang. This means that with increasing employee motivation, the performance of employees of the Engineering Department of PT. Semen Padang.

5. Compensation has a significant effect on the performance of employees of the Department of Engineering PT. Semen Padang. This means that with the increase in employee compensation it will also increase the performance of employees of the Engineering Department of PT. Semen Padang. 
6. Motivation indirectly has a significant effect through job satisfaction on the performance of employees of the Department of Engineering PT. Semen Padang. This means that with the increase in employee motivation influences job satisfaction, it will also improve the performance of employees of the Engineering Department of PT. Semen Padang.

7. Indirect compensation does not have a significant effect through job satisfaction on the performance of employees of the Department of Engineering PT. Semen Padang. This means that with increasing employee compensation no effect on job satisfaction and does not affect the performance of employees of the Department of Engineering PT. Semen Padang.

\section{Suggestions}

Based on the results of the analysis of the conclusions above, several suggestions can be given, including:

\section{Company}

\section{a. Motivation}

From the results of the questionnaire data on the motivational variables, the results obtained were that the lack of appreciation from the company towards employees was not in line with expectations. So, it is recommended that in the future PT. Semen Padang pays more attention to what employees have done and what employees have provided, so that they can give an appreciation that can increase employee motivation.

\section{b. Compensation}

From the results of the questionnaire data on the compensation variable, the results obtained are that the lack of an incentive given by the company is not in line with expectations. So, it is recommended that in the future PT. Semen Padang is more concerned with work incentives to be adjusted to the loyalty and performance provided by the company and in accordance with the profits obtained by the company.

\section{c. Job satisfaction}

From the results of the questionnaire data on the variable job satisfaction, the results are obtained that does not make the level of education of employees as a consideration of promotion. So, it is recommended that in the future PT. Semen Padang is more concerned with the promotion of employees, in the future it can also consider and pay attention to employees who continue their education and have completed higher levels of education to be considered promotional so that they can increase job satisfaction of PT. Semen Padang.

\section{d. Employee performance}

From the results of the questionnaire data on employee performance variables, the results obtained are that there are still employees who make mistakes in doing the work that is their responsibility. So, it is recommended that in the future PT. Semen Padang pays more attention to employee performance on how employees work according to standard operational procedure (SOP) and whether they have upheld K3 discipline in their work, and are expected to conduct evaluations more often to do more stabilization in producing good work results.

\section{Academics}

This research is expected to be a reference material for further research in accordance with the theme, namely motivation, compensation, job satisfaction and employee performance. Of course, in this study there are still many shortcomings. It does not rule out the possibility that there are still other variables outside the variables used in this study that can affect employee performance. Future research that is still themed employee performance is expected to be a complement or refinement of research. 


\section{BIBLIOGRAPHY}

A.Muri Yusuf. 2014. Quantitative, Qualitative Research and Combined Research Methodology. Jakarta: Prenadamedia Group.

Afriansyah, Ardy. 2014. Effect of Compensation and Work Conflict on Employee Performance (Study at the Office of PT Pos Indonesia (PERSERO) Mail Processing Center Semarang). ESSAY. Diponegoro University.

Alvina, 2013. Effects of Motivation, Compensation Through Job Satisfaction on Employee Performance (Case Study of Employees at PT. Pelindo III Semarang). ESSAY. Diponegoro University.

Arikunto, S. 2002. Research Procedures, A Practice Approach. Jakarta: PT. Rineka Cipta.

Bangun, W. 2012. Human Resource Management. Jakarta, Erlangga Publisher.

Bungin, Burhan. 2010. Qualitative Research Methods. Rajawali Press. Jakarta.

Darmadi, Hamid. 2014. Educational and Social Research Methods. Bandung: Alfabeta Bandung

Damayanti. 2013. Effect of Compensation and Work Motivation on the Employee Performance of Surakarta Regional Water Company (PDAM). Jupe Uns, vol 2, no.1.

Doni Pratama. 2015. Effect of Compensation and Motivation on Employee Performance with Job Satisfaction as an Intervening Variable at the Semarang Mail Processing Center. Semarang State University.

Edwin B. Flippo. 1990. Personnel Management. Erlangga

George and Jones. 2002. Organizational Behavior (3rd), USA: Prentice Hall

Ghozali, Imam. 2013. Application of Multivariate Analysis with the SPSS Program. Diponegoro University Publishing Agency, Semarang.

Hasibuan, M.S.P. 2012. Human Resource Management. Jakarta, Bumi Aksara Publisher.

Imam Swi Dagde. 2016. The Effect of Work Motivation on Performance with Job Satisfaction as an Intervening Variable in Nurses in the Inpatient Room of the Praya Regional General Hospital. Postgraduate Program in Master of Management, University of Muhammadiyah Yogyakarta.

Kadarisman, M. 2016. Compensation Management, Jakarta: Rajawali Press.

Kalangi, Rosje. 2015, Human Resource Development and Performance of State Civil Servants in the Sangihe Islands Regency of North Sulawesi Province. Journal of LPPM EkososBudKum Vol.2 No.1.

Mangkunegara, A.A.A.P. 2013. Corporate Human Resource Management, Youth Rosdakarya, Bandung.

Murty, W.A., Gunasti H. 2012. Effect of Compensation, Motivation and Organizational Commitment on Kryawan Performance in the Accounting Section (Case study in manufacturing companies in Surabaya). The Indonesian Accounting Review, Volume 2, No.2.

Maslow A.H. 2013. A Theory of Human Motivation. CreateSpace Independent Publishing Platform.

Masud. 2014. Concept and Application Organizational Diagnosis Survey. Jakarta. Erlangga.

Ni Made Nurcahyani, I.G.A. Dewi Adnyani. 2016. Effect of Compensation and Motivation on Employee Performance with Job Satisfaction as Intervening Variables at PT. Sinar Sosro Factory in Bali. E-Journal of Management of Unud, Vol. 5, No.1, 2016: 500 - 532.

Noor, Juliansyah, 2014. Research Methods. Kencana. Jakarta.

Nugroho and Kunartinah. 2012. Effect Analysis of Compensation and Career Development on Job Satisfaction with Mediation of Work Motivation. Journal of Business and Economics, Volume 19 Number 2.

Nurul Hidayah. 2016. Effects of Compensation on Employee Performance with Job Satisfaction As Intervening Variables Case Study at Finance and Accounting Employees in Yogyakarta State University, Yogyakarta, Indonesia.

Prastusi, 2014. Effect of Good Corporate Governance on Corporate Values with Corporate Social Responsibility as a Moderating Variable. Economics and Business Journal (3) (3).

Rati Nawastuti. 2018. Effects of Motivation and Compensation on Employee Performance with Job Satisfaction As Intervening Variables Case Study at PT. State Savings Bank, Tbk Semarang Sharia Branch Office. SKRIPSI, Islamic Banking, Faculty of Economics and Business, Islamic Institute of Islamic Studies, Salatiga, Indonesia.

Rachmawati, I.K. 2008. Human Resource Management. Yogyakarta: Andi.

Rivai. 2010. Human Resource Management for Companies from Theory to Practice, Jakarta: Raja Grafindo Persada. 
Robbins, Stephan P and Timothy A. Judge. 2009. Organizational Behavior (Organizational Behavior). Jakarta: Salemba Empat.

Simamora, H. 2004. Human Resource Management. Yogyakarta: STIE YKPN.

Slamet, Achmad. 2007. Human Resources. UNNES Press. Semarang

Sofyandi, Herman \& Iwa Garniwa. 2008. Organizational Behavior. Yogyakarta: Graha Ilmu.

Sugiyono. 2002. Statistics for Research. Bandung: Alfabeta.

Sugiyono. 2016. Quantitative, Qualitative Research and R \& D Methodology. Bandung: Alfabeta.

Suryabrata, Sumadi. 2014. The 25th Print Research Methodology. Jakarta: PT Raja Grafindo Persada.

Now, Uma. 2006. Research Methodology for Business, Fourth Edition. Jakarta: Salemba Empat Publisher.

Now, Uma and Roger Bougie. 2010. Issue 5, Research Method For Business: A Skill Building Approach. John Wiley @ Sons, New York.

Wibowo. 2014. Performance management. Jakarta: PT Rajagrafindo Persada. 